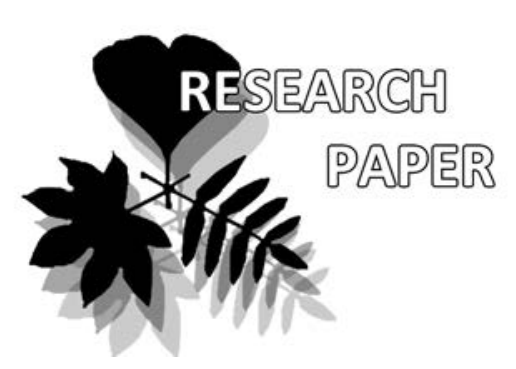

Vadim A. Bakalin ${ }^{1 *}$

e-mail: vabakalin@gmail.com

Anna Vilnet ${ }^{2}$

e-mail: anya_v@list.ru

${ }^{1}$ Botanical Garden-Institute FEB RAS, Vladivostok, Russia

${ }^{2}$ Polar-Alpine Botanical Garden-Institute of Kola SC RAS, Kirovsk, Russia

* corresponding author

Manuscript received: 19.07.2018 Review completed: 30.10 .2018 Accepted for publication: 31.10.2018

Published online: 05.11.2018

\section{Note on taxonomic position and distribution of Hygrobiella nishimurae N. Kitag. (Hygrobiellaceae, Marchantiophyta)}

\author{
Vadim A. Bakalin ${ }^{1 *} \&$ Anna A. Vilnet ${ }^{2}$
}

\begin{abstract}
A B S T R A C T
The taxonomic position of Hygrobiella nishimurae, an enigmatic East Asian rarity, was identified using integrative approach, including DNA analysis, conducted for the first time for the species. This taxon was described under Hygrobiella, then placed into Metabygrobiella and finally to Cephalozia, however belongs to the former genus - the point of view that is not widely accepted now. In the course of our works this taxon (before regarded as Japanese endemic) was revealed for the first time in Korean Peninsula. The paper provides review of the genus taxonomy, distribution, descriptions and figures based on available material.
\end{abstract} Ke y w o r d s : Hygrobiella, East Asia, Hygrobiellaceae, taxonomy, Hepaticae

\section{P E 3 Ю ME}

Бакалин В.А., Вимьнет А.А. О таксономическом положении и распространении Hygrobiella nishimurae N. Kitag. (Hygrobiellaceae, Marchantiophyta). Таксономическое положение Hygrobiella nishimurae - малоизвестного восточноазиатского виАа, определено с помощью интегративного подхода, включая молекулярно-генетические исследования, проведенные Аля этого вида впервые. Таксон, который был описан как Hygrobiella, затем перемещен в Metabygrobiella и, наконец, в Cephalozia, принадлежит к первому роду, что в настоящее время не является широко признанным. В ходе работы виА, ранее рассматривавшийся как эндем Японии, был выявлен впервые на Корейском помуострове. Работа содержит замечания по таксономической структуре рода, а также описание и ил^юстрации на основании изучения доступного материала. Ккючевые слов а: Hygrobiella, Восточная Азия, Hygrobiellaceae, таксономия, Hepaticae
Hygrobiella nishimurae N. Kitag. was described based on the complex of features uncharacteristic in the genus, including strongly distichously leaved plants, conduplicate and keeled leaves and the absence of underleaves. These features were as drastically different from that of $H$. laxifolia - the only taxon known in the genus at that time - as this new species was at the same time placed to the newly described subgenus Hygrobiella subg. Pterocephalozia N. Kitag. (Kitagawa 1982). This strongly different look resulted the position of this genus was doubted soon after the description. As soon as two years later it was transferred to Metahygrobiella on the basis of absence of underleaves (Grolle 1984), despite no Metabygrobiella had similarly distichously leaved plants and at least the most of them are soft textured and resembling Cephalozia. The placement of Hygrobiella nishimurae to Metabygrobiella was not followed by Yamada \& Iwatsuki (2006).

Despite aforementioned contradiction, Hygrobiella nishimurae was housed in Metabygrobiella for 30 years, until Váňa et al. (2013) have transferred it to Cephalozia, as C. nishimurae (N. Kitag.) Váňa. The latter transfer (Váňa et al. 2013) was the result of formalistic approach to provide new names for the 9 taxa before regarded to Metabygrobiella on the basis of two taxa (M. albula (Steph.) Grolle and M. macgregorii (Steph.) R.M. Schust.) which were found by Feldberg et al. (2013) as members of Cephalozia s. str. No more 'Me- tabygrobiella' taxa were studied genetically by Feldberg et al. (2013). Therefore, the first transfer Hygrobiella nishimurae to Metabygrobiella was accomplished by the second transfer to Cephalozia, regardless the striking contrast in appearance of Hygrobiella nishimurae with other Cephalozia. The latter point of view was adopted in the World checklist of liverworts and hornworts (Söderström et al. 2016).

Recently V. Bakalin was able to study type materials of the species as well as some other materials in Japanese herbaria and to collect this peculiar species both in Japanese Shikoku and southernmost flank of the Republic of Korea. To check the position of this species and to discuss the distribution of the taxon were the primary goal of the present paper that was conducted using integrative approach.

\section{MATERIAL AND METHODS Herbarium materials}

The material discussed in the paper was collected in the course of field researches in Japan and the Republic of Korea in summer of 2015. After collecting the material was transferred to VBGI and morphologically studied. Other herbarium specimens cited below were studied in 2014 when the first author visited KYO and HIRO. The only specimen we were able to extract DNA was the Japanese specimen (J-11-42-15). The Korean specimen was not sequenced due 
to very scarce amount of the material. The total list of specimens examined is placed below:

Specimens examined: JAPAN. Hiroshima Pref., Ohouki Mt., $790 \mathrm{~m}$ alt., wet rocks in the valley, Nakashima M., 3672, 15.IX.1981 (KYO, s.n.); ibid., Hiramidani, $620 \mathrm{~m}$ alt., stone near stream in deciduous forest, Nakashima M., 3850 \& 3849(a), 26.X.1981 (HIRO, s.n.); ibid., $640 \mathrm{~m}$ alt., wet rocks near stream, Nakashima M., 3748, 17.X.1981 (HIRO); Kochi Pref., Nagaoka-gun, Ou, Shiofuri Falls (334' $09^{\prime \prime N}$ 13341'15"E), $500 \mathrm{~m}$ alt., Bakalin V.A., J-11-42-15, 25.III.2015 (VBGI); Oita Pref., Kamitue-mura, Sasano, $600 \mathrm{~m}$ alt., on wet rock, riverside, Nishimura N., 8459, 29.VII.1981 (holotype of the taxon, KYO; isotype HIRO); Wakayama Pref., Tanagadani , $300 \mathrm{~m}$ alt., moist rock, Kodama T., 46730, 26.XII.1973 (KYO). REPUBLIC OF KOREA. Jeju Island,

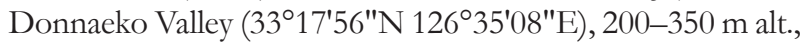
Bakalin V.A., Kor-30-58-15, 14.V.2015 (VBGI).

\section{Taxon sampling}

To test phylogenetic affinity of Japanese specimen (J-1142-15) morphologically identified as Hygrobiella nishimurae we implemented a BLAST search (https://blast.ncbi.nlm.nih. gov) for the firstly sequenced DNA loci. The similarity of tested specimen with the genus Higrobiella achieved 87-91\% in ITS2, $96 \%$ in trnL-F and $96-98 \%$ in $\operatorname{tr} n$ G-intron, the less level of similarity was suggested with other representatives of suborder Jungermanniineae and did not reveal relation to the genus Cephalozia. Thus, to support this find we produced a new dataset included three multiply sampled species of the genus Hygrobiella (Bakalin \& Vilnet 2014) and representatives of suborder Jungermanniineae according with phylogeny demonstrated in Shaw et al. (2015) and World checklist of liverworts and hornworts (Söderström et al. 2016). In total, 27 nucleotide sequences of ITS1-5.8 $r \mathrm{DNA}, 50$ of $\operatorname{trn} \mathrm{L}-\mathrm{F}$ and 45 of $t r n$ G-intron cpDNA presented 59 specimens from 38 species belonging to 33 genera and 18 families of suborder Jungermanniineae, were combined in the dataset. The nucleotide sequences data for 76 accessions were taken from previous studies (Yatsentyuk et al. 2004, Vilnet et al. 2010, 2012, Bakalin \& Vilnet, 2012, 2014, Bakalin et al. 2015, Mamontov et al. 2018, unpublished data) and 31 accessions were downloaded from GenBank. For Mesoptychia sablbergii (Lindb.) A. Evans DNA data were combined from two specimens. The genus Southbya Spruce was represented by sequence data from Southbya gollanii Steph. and Southbya nigrella (De Not.) Henriq. For eight specimens three ITS1-5.8, four trnL-F and seven $\operatorname{trn} \mathrm{G}$-intron nucleotide sequences were newly generated. All analyzed specimens are listed in Table 1, including GenBank accession numbers and voucher details.

\section{DNA isolation, PCR amplification and DNA sequencing}

DNA was extracted from dried liverwort tissue using the NucleoSpin Plant Kit (Macherey-Nagel, Germany). The amplification and sequencing were performed using primers suggested by White et al. (1990) for ITS1-5.8S rDNA, Taberlet et al. (1991) for trnL-F, Shaw et al. (2005) for trnG-intron.

PCR were carried out in $20 \mu \mathrm{l}$ volumes according to the following procedure: $3 \mathrm{~min}$ at $94^{\circ} \mathrm{C}, 30$ cycles $\left(30 \mathrm{~s} 94^{\circ} \mathrm{C}\right.$,
$40 \mathrm{~s} 56^{\circ} \mathrm{C}$ (ITS1-5.8S rDNA, trnL-F) or $64^{\circ} \mathrm{C}$ (trnG-intron), $60 \mathrm{~s} 72^{\circ} \mathrm{C}$ ) and $2 \mathrm{~min}$ of extension time at $72^{\circ} \mathrm{C}$. Amplified fragments were visualized on $1 \%$ agarose TAE gels by EthBr staining, purified using the GFX ${ }^{\mathrm{TM}}$ PCR DNA and Gel Band Purification Kit (Amersham Biosciences, USA), and then used as a template in sequencing reactions with the ABI Prism BigDye Terminator Cycle Sequencing Ready Reaction Kit (Applied Biosystems, USA) following the standard protocol provided for 3100 Avant Genetic Analyzer (Applied Biosystems, USA).

\section{Phylogenetic analysis}

Three datasets (ITS1-5.8S rDNA, trnL-F and trnG-intron) were automatically aligned in BioEdit 7.0.1 (Hall 1999) with ClustalW option and then manually corrected. The preliminary phylogenetic analyses revealed a lack of incongruence between all datasets and then a combined alignment was produced. All positions of the final alignment were included in the phylogenetic analysis, absent data was coded as missing.

The combined ITS1-5.8S+trn L-F+trnG-intron alignment was analyzed only by the maximum likelihood method (ML) with PhyML v. 3.0 (Guindon et al. 2010) due to absence of nucleotide sequence data for one or two loci at a number of specimens. The $\mathrm{TN}+\mathrm{I}+\mathrm{G}$ model was selected as the best-fit evolutionary model of nucleotide substitutions for alignment using the ModelGenerator software (Keane et al. 2004). In ML analysis this model was used and the rate heterogeneity among sites was modeled using a gamma distribution with four rate categories. Bootstrap support (BS) for individual nodes was assessed using a resampling procedure with 300 replicates. According to the stopping frequency criterion (FC) for bootstrapping procedure (Pattengale et al. 2010) for our dataset 300 replicates were enough for reaching BS convergence with Pearson average $\varrho 100=0.994064$ as estimated by RAxML v. 7.2.6 (Stamatakis 2006). The calculation of infrageneric and infraspecific distances ( $\mathrm{p}$-distances) for the genus Hygrobiella was provided with Mega 5.1 (Tamura et al. 2011), obtained results are shown in Table 2.

\section{RES U LT S}

The newly generated 14 nucleotide sequences were deposited in GenBank. The combined ITS1-5.8S + trnL-F + $\operatorname{trn} \mathrm{G}$-intron alignment for 57 specimens consists of 1871 character sites, among them 551 sites belong to ITS1-5.8S, 588 sites - to trnL-F and 732 sites - to trnG-intron. The number of invariable sites in ITS1-5.8S, trnL-F and $\operatorname{trnG}$ intron are $326(59.17 \%), 247$ (42\%) and 221 (30.19\%), variable positions are 209 (37.93\%), 327 (55.61\%) and $480(65.57 \%)$, parsimony informative positions are 117 $(21.23 \%), 229(38.94 \%)$ and $327(44.67 \%)$. In the combined alignment there are $794(42.43 \%)$ invariable sites, $1016(54.30 \%)$ variable and $673(18.49 \%)$ parsimony informative positions.

The ML calculation resulted in a tree with Log likelihood of -16135.234549 , the obtained tree topology is shown on Fig. 1 with indication of bootstrap support values (BS). The phylogenetic affinity within suborder Jungermanniineae is 
Table 1. The list of taxa, specimen vouchers and GenBank accession numbers. The newly obtained sequences are in bold, the sequences downloaded from GenBank are in italic.

\begin{tabular}{|c|c|c|c|c|}
\hline \multirow[t]{2}{*}{ Taxon } & \multirow[t]{2}{*}{ Specimen voucher } & \multicolumn{3}{|c|}{ GenBank accession number } \\
\hline & & $\begin{array}{l}\text { ITS1-5.8 } \\
\text { nrDNA }\end{array}$ & $\begin{array}{l}\text { trnL-F } \\
\text { cpDNA }\end{array}$ & $\begin{array}{l}\text { trnG-intron } \\
\text { cpDNA }\end{array}$ \\
\hline $\begin{array}{l}\text { Acrobolbus ochrophyllus (Hook. f. \& Taylor) } \\
\text { R.M. Schust. }\end{array}$ & Chile, Engel, 26633 (F) & no data & KJ802071 & KJ802044 \\
\hline Anthelia julacea (L.) Dumort. & Scotland, Long, 31292 (E) & no data & KJ802043 & KJ802070 \\
\hline Arnellia fennica (Gottsche) Lindb. & Finland, Shaw, 1250 (DUKE) & no data & KJ802096 & KJ802058 \\
\hline Balantiopsis cancellata (Nees) Steph. & Chile, Hyvonen, 5946 & no data & AY463545 & no data \\
\hline $\begin{array}{l}\text { Blepharidophyllum vertebrale (Taylor ex Gott- } \\
\text { sche, Lindenb. \& Nees) Angstr. ex C. Massal. }\end{array}$ & New Zealand, Engel \& von Konrat (F) & no data & KJ802086 & no data \\
\hline Calypogeia muelleriana (Schiffn.) Müll. Frib. & $\begin{array}{l}\text { Russia: Perm Prov., Konstantinova, K 367-1-04 } \\
\text { (KPABG) }\end{array}$ & JX629935 & JX630062 & no data \\
\hline Delavayella serrata Steph. & Chuna: Yunnan, Long, 34809 (E) & no data & KJ802066 & KJ802037 \\
\hline $\begin{array}{l}\text { Endogemma caespiticia (Lindenb.) Konstant., } \\
\text { Vilnet \& A.V. Troitsky }\end{array}$ & Austria, Sova (DUKE) & no data & KF943088 & KF942925 \\
\hline $\begin{array}{l}\text { Eremonotus myriocarpus (Carrington) } \\
\text { Pearson }\end{array}$ & $\begin{array}{l}\text { Russia: Karachaevo-Cherkesia Rep., Konstantinova, K } \\
\text { 446-6-05 (KPABG) }\end{array}$ & EU791839 & EU791716 & no data \\
\hline Gymnomitrion commutatum (Limpr.) Schiffn. & $\begin{array}{l}\text { Russia: Kamchatka Territory, Bakalin, K-51-7-03, } \\
105602 \text { (KPABG) }\end{array}$ & MF521469 & JF421596 & no data \\
\hline Geocalyx graveolens (Schrad.) Nees & China: Yunnan, Long, 34828 (E) & no data & KJ802067 & KJ802038 \\
\hline Gongylanthus renifolius (Mitt.) Steph. & South Africa, de Roo s.n. (BOL) & no data & no data & AM397717 \\
\hline Gyrothyra underwoodiana M. Howe & USA: Oregon, Shaw, F886 (DUKE) & no data & KJ802103 & KJ802063 \\
\hline Harpanthus flotovianus (Nees) Nees & Norway, Long \& Schill, 31355 (E) & no data & KJ802065 & KJ802039 \\
\hline \multirow[t]{4}{*}{ Hygrobiella intermedia Bakalin et Vilnet } & $\begin{array}{l}\text { Russia: Central Kamchatka, Bakalin, 90-8-01-VB, } \\
103960 \text { (KPABG) }\end{array}$ & no data & KF008581 & KF008638 \\
\hline & $\begin{array}{l}\text { Russia: Sakhalin Prov., Kuril I. Chain, Iturup Isl., Baka- } \\
\text { lin, K-70-3-05 (VLA), duplicate } 115584 \text { (KPABG), } 1\end{array}$ & - KF008621 & no data & no data \\
\hline & $\begin{array}{l}\text { Russia: Sakhalin Prov., Kuril I. Chain, Iturup Isl., Baka- } \\
\text { lin, K-71-8-05 (VLA), duplicate } 115583 \text { (KPABG), } 2\end{array}$ & - no data & KF008583 & KF008640 \\
\hline & $\begin{array}{l}\text { Russia: Sakhalin Prov., Kuril I. Chain, Shikotan } \\
\text { Isl., Bakalin, K-48-13-07 (VLA), duplicate } 115589 \\
\text { (KPABG) }\end{array}$ & KF008620 & KF008582 & KF008639 \\
\hline \multirow[t]{13}{*}{ Hygrobiella laxifolia (Hook.) Spruce } & Canada, Urmi, 8852 (dupla in VGBI), 1 & MH580595 & MH580590 & MH580598 \\
\hline & Canada, Urmi, 8861 (dupla in VGBI), 2 & no data & MH580591 & MH580599 \\
\hline & $\begin{array}{l}\text { Russia: Commander Islands, Bering Isl., Bakalin, K-6- } \\
\text { 6-02-VB, } 103449 \text { (KPABG) }\end{array}$ & KF008616 & KF008571 & KF008636 \\
\hline & $\begin{array}{l}\text { Russia: Khanty-Mansi Autonomous Area, Lapshina, } \\
\text { 13-256 t. } 11 \text { (dupla in KPABG), } 1\end{array}$ & no data & no data & MH580601 \\
\hline & $\begin{array}{l}\text { Russia: Khanty-Mansi Autonomous Area, Lapshina, } \\
\text { 13-262 t.11 (dupla in KPABG), } 2\end{array}$ & no data & no data & MH580600 \\
\hline & $\begin{array}{l}\text { Russia: Khanty-Mansi Autonomous Area, Lapshina, } \\
\text { 13-267 t.11 (dupla in KPABG), } 3\end{array}$ & no data & no data & MH580602 \\
\hline & $\begin{array}{l}\text { Russia: Murmansk Prov., Konstantinova, 115/1 } \\
(\mathrm{KPABG}), 1\end{array}$ & KF008613 & KF008568 & KF008632 \\
\hline & $\begin{array}{l}\text { Russia: Murmansk Prov., Konstantinova, } 5171 \\
\text { (KPABG), } 2\end{array}$ & KF008612 & KF008567 & KF008631 \\
\hline & $\begin{array}{l}\text { Russia: Murmansk Prov., Konstantinova, 15-1-98, } 6984 \\
\text { (KPABG), } 3\end{array}$ & 4 JX629933 & JX630052 & KF008627 \\
\hline & $\begin{array}{l}\text { Russia: Murmansk Prov., Konstantinova, 29-1-94 } \\
\text { (KPABG), } 4\end{array}$ & KF008611 & AF519187 & KF008626 \\
\hline & $\begin{array}{l}\text { Russia: Murmansk Prov., Konstantinova, 152-7-87, } \\
6103 \text { (KPABG), } 5\end{array}$ & KF008614 & KF008569 & KF008633 \\
\hline & $\begin{array}{l}\text { Russia: Murmansk Prov., Konstantinova, K 110-1-11, } \\
20180 \text { (KPABG), } 6\end{array}$ & KF008610 & KF008565 & KF008625 \\
\hline & USA, Konstantinova, A108/1-95 (KPABG) & KF008619 & KF008572 & KF008635 \\
\hline Hygrobiella nishimurae N. Kitag. & Japan, Bakalin, J-11-42-15 (KPABG, VGBI) & MH580594 & MH580592 & MH580603 \\
\hline \multirow[t]{6}{*}{ Hygrobiella squamosa Bakalin et Vilnet } & $\begin{array}{l}\text { Russia: Commander Islands, Medny Isl., Bakalin, K-67- } \\
2-04,106771 \text { (KPABG) }\end{array}$ & -KF008618 & KF008578 & KF008647 \\
\hline & $\begin{array}{l}\text { Russia: Central Kamchatka, Bakalin, KK 50-24a-02- } \\
\text { VB, } 104117 \text { (KPABG) }\end{array}$ & no data & KF008575 & KF008641 \\
\hline & $\begin{array}{l}\text { Russia: Krasnoyarsk Territory, Taimyr, Fedosov, 11-232 } \\
\text { (KPABG) }\end{array}$ & 2 no data & no data & MH580597 \\
\hline & $\begin{array}{l}\text { Russia: Sakhalin Prov., Kuril I. Chain, Iturup Isl., Baka- } \\
\text { lin, K-12-6-07 (VLA), duplicate } 115588 \text { (KPABG), } 1\end{array}$ & - no data & KF008584 & KF008648 \\
\hline & $\begin{array}{l}\text { Russia: Sakhalin Prov, Kuril I. Chain, Iturup Isl., Baka- } \\
\text { lin, K-12-8a-07 (VLA), duplicate } 115587 \text { (RPABG), } 2\end{array}$ & - no data & KF008585 & KF008649 \\
\hline & $\begin{array}{l}\text { Russia: Sakhalin Prov., Kuril I. Chain, Paramushir Isl., } \\
\text { Bakalin, K-106-7-04, } 107584 \text { (KPABG) }\end{array}$ & no data & KF008580 & KF008645 \\
\hline Isotachis lyallii Mitt. & New Zealand, Engel, 21825 (F) & no data & AY608130 & AY608178 \\
\hline
\end{tabular}


Table 1. Continued.

\begin{tabular}{|c|c|c|c|c|}
\hline \multirow[t]{2}{*}{ Taxon } & \multirow[t]{2}{*}{ Specimen voucher } & \multicolumn{3}{|c|}{ GenBank accession number } \\
\hline & & $\begin{array}{l}\text { ITS1-5.8 } \\
\text { nrDNA }\end{array}$ & $\begin{array}{l}\text { trnL-F } \\
\text { cpDNA }\end{array}$ & $\begin{array}{l}\text { trnG-intron } \\
\text { cpDNA }\end{array}$ \\
\hline Jungermannia atrovirens Dumort. & $\begin{array}{l}\text { Russia: Caucasus, Karachaevo-Cherkesia Rep., Ignatov, } \\
\text { Ignatova MHA 4.8.02 (KPABG) }\end{array}$ & GQ220782 & GQ220766 & no data \\
\hline Lethocolea glossophylla (Spruce) Grolle & Ecuador, Davis, 259 (DUKE) & no data & KJ802080 & KJ802051 \\
\hline Liochlaena lanceolata Nees & $\begin{array}{l}\text { Russia: Vladimir Prov., Kokoshnikova, } 112323 \\
\text { (KPABG) }\end{array}$ & KF516120 & KF516228 & KF516172 \\
\hline $\begin{array}{l}\text { Marsupella funckii (F. Weber \& D. Mohr) } \\
\text { Dumort. }\end{array}$ & $\begin{array}{l}\text { Russia: Karachaevo-Cherkessia Rep., Konstantinova, } \\
\text { K516-1-05, } 109804 \text { (KPABG) }\end{array}$ & EU791820 & EU719700 & no data \\
\hline $\begin{array}{l}\text { Mesoptychia chinensis Bakalin, Vilnet et } \\
\text { Xiong }\end{array}$ & $\begin{array}{l}\text { China: Guizhou Prov., Bakalin, China-51-11-13 } \\
\text { (KPABG) }\end{array}$ & no data & KM501488 & KM501472 \\
\hline Mesoptychia sablbergii (Lindb.) A. Evans & $\begin{array}{l}\text { Russia: Chukotka, Afonina, 10.VIII.1979 (KPABG) } \\
\text { Russia: East Siberia, Ionatov, s.n. (BOL) }\end{array}$ & $\begin{array}{l}\text { EU791840 } \\
\text { no data }\end{array}$ & $\begin{array}{l}\text { AF519189 } \\
\text { no data }\end{array}$ & $\begin{array}{l}\text { no data } \\
A M 397757\end{array}$ \\
\hline Metacalypogeia cordifolia (Steph.) Inoue & $\begin{array}{l}\text { Russia: Primorsky Kray, Bakalin, P-66-18a-06 } \\
\text { (KPABG) }\end{array}$ & JX629934 & JF421597 & no data \\
\hline Metasolenostoma orientale Bakalin \& Vilnet & $\begin{array}{l}\text { Russia: Kamchatka, Bakalin, HPE 42, 29.08.2001 } \\
\text { (KPABG) }\end{array}$ & GQ2 & AY327777 & JQ828698 \\
\hline Nardia compressa (Hook.) Gray & Canada, Konstantinova, A97/1-95 (KPABG) & EU791837 & AF519188 & no data \\
\hline Notoscyphus lutescens (Lehm. \& Lindenb.) Mitt. & Australia, Pocs, 01098/d (DUKE) & no data & KJ802099 & KJ802060 \\
\hline Plectocolea obovata (Nees) Mitt. & $\begin{array}{l}\text { Russia: Kemerovo Prov., Konstantinova, 72-2-00, } \\
102004 \text { (KPABG) }\end{array}$ & GQ220769 & GQ220753 & JQ828678 \\
\hline Poeltia campylata Grolle & China: Sichuan, Bakalin, China-48-2-17, 37210 (VGBI) & MH580596 & MH580593 & no data \\
\hline Prasanthus suecicus (Gottsche) Lindb. & $\begin{array}{l}\text { Norway: Svalbard, Konstantinova, K 121-5-06 } \\
\text { (KPABG) }\end{array}$ & EU791825 & EU791704 & no data \\
\hline Saccogynidium australe (Mitt.) Grolle & New Zealand, Engel, von Konrat \& Braggins, 24166 (F) & no data & KF942960 & KF942832 \\
\hline Solenostoma confertissimum (Nees) Schljakov & $\begin{array}{l}\text { Russia: Karachayevo-Cherkessian Rep., K 459-8a-05, } \\
10968 \text { (KPABG) }\end{array}$ & GQ220774 & GQ220758 & JQ828781 \\
\hline Southbya gollanii Steph. & Nepal, Long, 30537 (E) & no data & no data & AM397739 \\
\hline Southbya nigrella (De Not.) Henriq. & Italy, Buryova, 621 (DUKE) & no data & KJ802083 & no data \\
\hline Stephaniella paraphyllina J.B. Jack & Venezuela, Soederstroem, 2004/030b (BOL) & no data & no data & AM397698 \\
\hline Trichotemnoma corrugatum (Steph.) R.M. Schu & Glenny, 8426 & no data & AY463591 & no data \\
\hline
\end{tabular}

Table 2. The value of infrageneric and infraspecific $p$-distances for the genus Hygrobiella, $\mathrm{n} / \mathrm{c}-$ non calculated value due to single specimen only, “-“"non calculated value due to unsequenced DNA locus.

\begin{tabular}{|c|c|c|c|c|c|c|}
\hline \multirow{2}{*}{ Taxon } & \multirow{2}{*}{$\begin{array}{l}\text { Infraspecific p-distances, (ITS1- } \\
5.8 / \text { trnL-F / trnG-intron) } \%\end{array}$} & \multicolumn{5}{|c|}{ Infrageneric p-distances, (ITS1-5.8/trnL-F/trnG-intron) \% } \\
\hline & & H. laxifolia & H. squamosa & H. intermedia & H. nishimurae & Anthelia julacea \\
\hline Hygrobiella laxifolia & $0.8 / 0 / 0.1$ & & & & & \\
\hline H. squamosa & $\mathrm{n} / \mathrm{c} / 0.1 / 0.1$ & $5.0 / 2.1 / 3.0$ & & & & \\
\hline H. intermedia & $0 / 0 / 0.2$ & $4.5 / 2.6 / 2.7$ & $5.2 / 2.1 / 3.0$ & & & \\
\hline H. nishimurae & $\mathrm{n} / \mathrm{c} / \mathrm{n} / \mathrm{c} / \mathrm{n} / \mathrm{c}$ & $7.5 / 3.0 / 2.3$ & $6.6 / 3.4 / 2.3$ & $9.0 / 3.6 / 2.2$ & & \\
\hline Anthelia julacea & $-/ \mathrm{n} / \mathrm{c} / \mathrm{n} / \mathrm{c}$ & $-/ 7.1 / 9.0$ & $-/ 7.2 / 8.5$ & $-/ 6.5 / 8.8$ & $-/ 8.1 / 8.1$ & \\
\hline
\end{tabular}

common with those obtained by Shaw et al. (2015). The newly sequenced Japanese specimen of Hygrobiella nishimurae formed the basal branch in the clade of family Hygrobiellaceae, its relation to three other Hygrobiella species obtained $96 \%$ bootstrap support. The level of ITS1-5.8S sequence divergence of Hygrobiella nishimurae from the rest of Hygrobiella species counts $6.6-7.5 \%$ that almost in 1.5 higher then divergence between $H$. laxifolia, $H$. squamosa and $H$. intermedia (4.5-5.2 \%, Table 2). The value of $\operatorname{trn} \mathrm{L}-\mathrm{F}$ p-distances between Hygrobiella nishimurae and Hygrobiella spp. are 3.0-3.6 \% opposite to $2.1-2.6 \%$ between other Hygrobiella species. The $\operatorname{trn} \mathrm{G}$-intron data suggested lower level of divergence of $\mathrm{Hy}$ grobiella nishimurae (2.2-2.3\%) whereas three Hygrobiella species are more diverged from each other (2.7-3.0 \%).
Implemented phylogenetic estimation robustly proved initial treatment of Hygrobiella nishimurae as a member of the genus Hygrobiella and the level of nrDNA sequence divergence with a number of morphological features support its separation in the subgenus Pterocephalozia.

\section{DISCUSSION}

As it was found above, the robust morphological difference is accompanied with strong distance in the term of genetics. Hygrobiella nishimurae belongs to Hybrobiellaceae and is quite distanced from other bulk of the taxa of the genus therefore the subgenus Pterocephalozia should be recognized as it was proposed by Kitagawa (1982). The differences of $H$. nishimurae from other taxa are in strongly distichous 


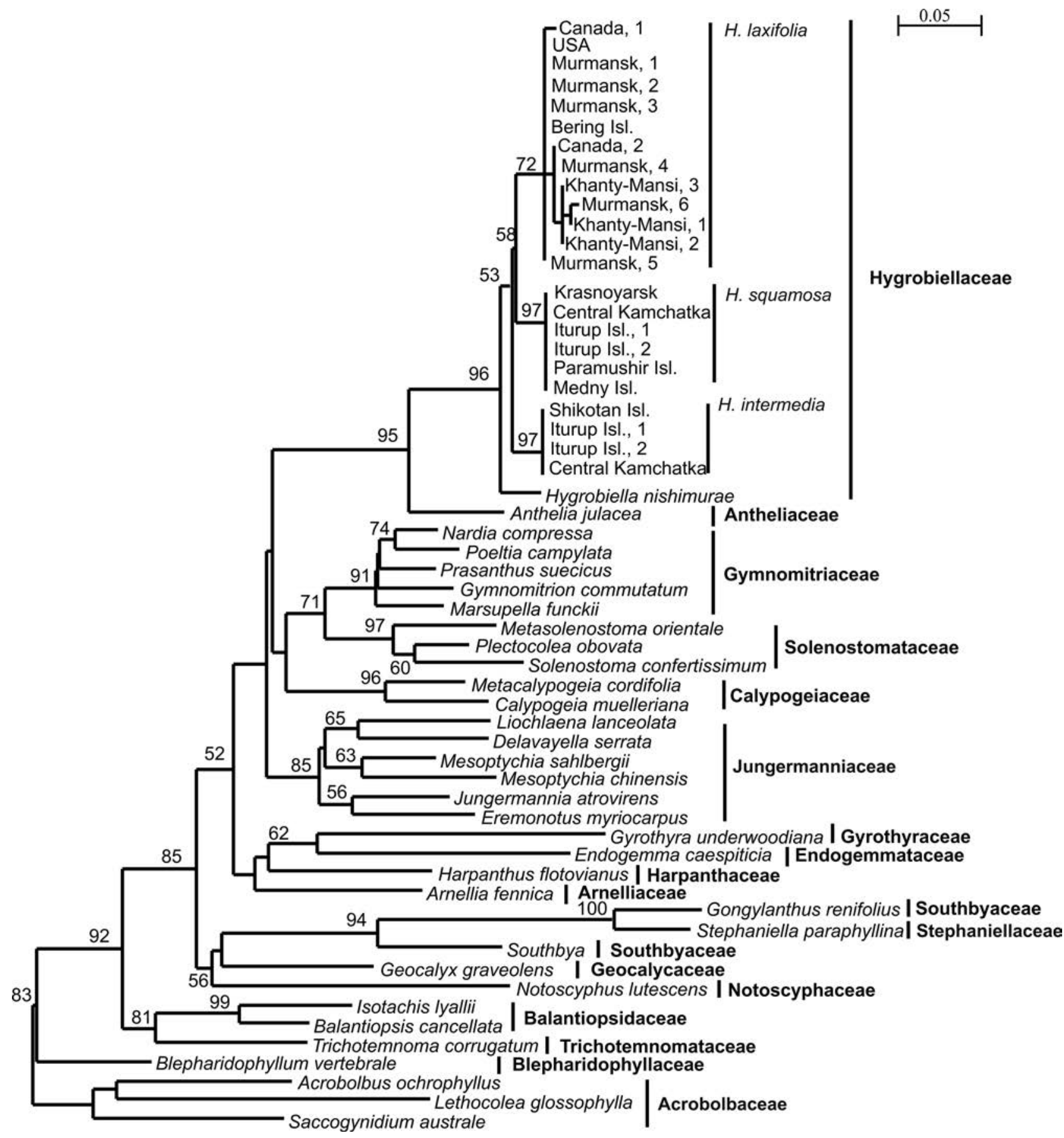

Figure 1 Maximum likelihood phylogenetic tree for the suborder Jungermanniineae based on combined dataset ITS1-5.8S $n r \mathrm{DNA}+\operatorname{trn} \mathrm{L}-$ $\mathrm{F}+\operatorname{trn} \mathrm{G}$-intron.Bootstrap support values are indicated

leaf arrangement and absence of underleaves. However, it worth to be noted although leaves are conduplicate in the majority of cases the keel wing may not be developed. The plants in paratype from Wakayama Pref. are even hardly winged. The plant size is the subject of the great variation, and sometimes differs in 2 or even 3 times that may be obvious from stem cross sections obtained from Japanese and Korean material (Fig. 2: 7-9). The color of plants is also the subject for variation. Indeed, the type specimen of the species is greenish brown, as indicated in original description; however, green coloration of plants is somewhat common in shady areas. Moreover some confusion in the coloration may arise from the color changes in the herbarium. The plants we collected in Shikoku were bright green in the wild conditions (Fig. 3: 1), but after complete dying become brownish pigmented. Since the material revealed in the course of this study enlarge data on the species variability below we provide the morphological description of the species. Since we did not find the generative structures in specimens collected by Bakalin, the information on them is adopted and shortened from Kitagawa (1982) and put into square brackets. 


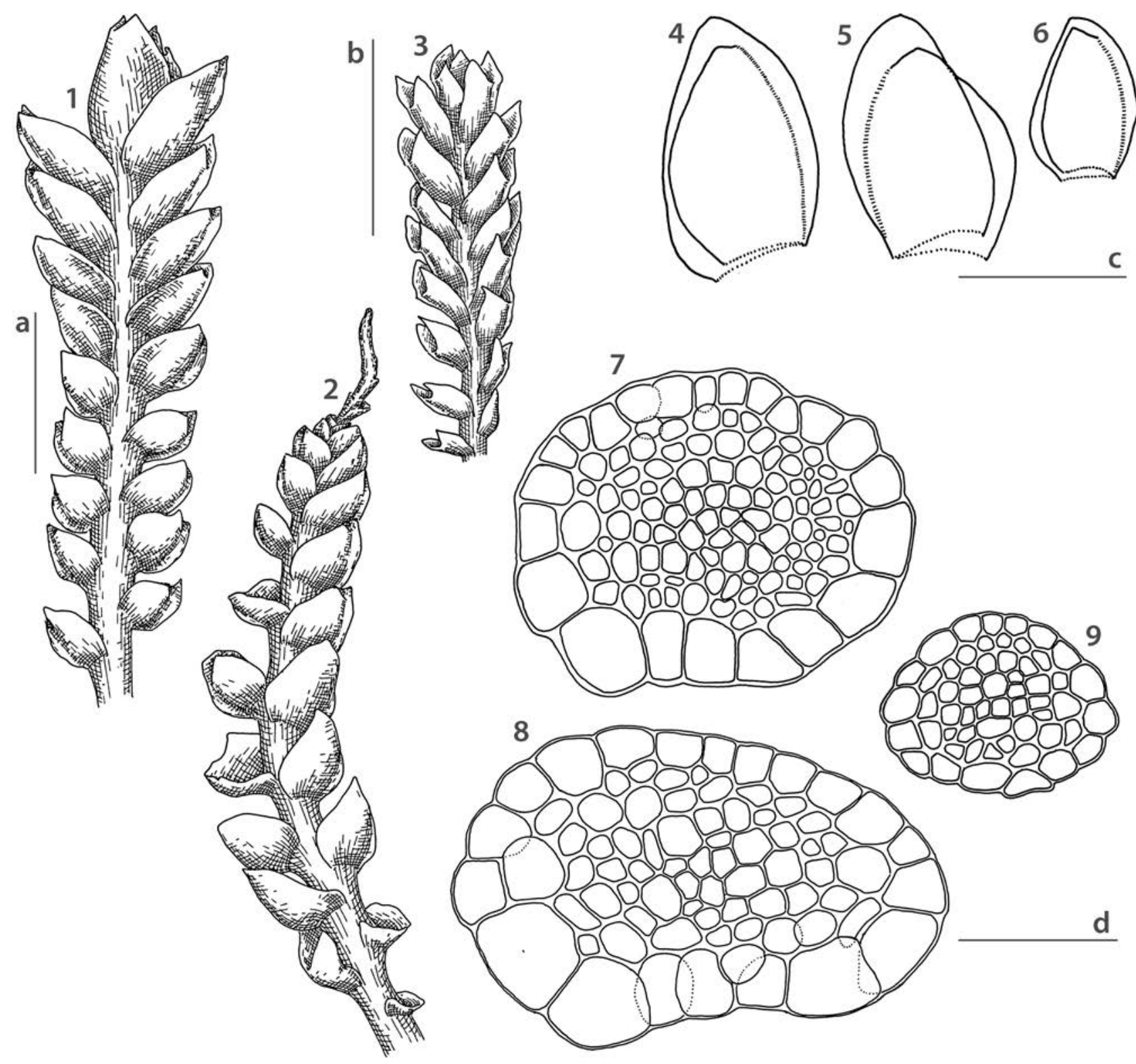

Figure 2 Hygrobiella nishimurae N. Kitag.: 1, 3 - plant habit, dorsal view; 2 - plant habit, ventral view; 4-6 - leaves; 7-9 - stem cross sections. Scales: $\mathrm{a}-1 \mathrm{~mm}$, for 1, 2; b - $1 \mathrm{~mm}$, for 3; c - 500 $\mu \mathrm{m}$, for 4-6; d - $100 \mu \mathrm{m}$, for 7-9. 1, 2, 4-7 - from Bakalin J-11-42-15 (VBGI); 3, 9 - from Bakalin Kor-30-58-15 (VBGI); 8 - from Kodama 46730 (KYO)

Hygrobiella nishimurae N. Kitag., Misc. Bryol. Lichenol. 9(4):69, 1982.

Plants bright green to brownish green when alive, become brownish to greenish brown in herbarium, strongly distichously leaved, with leaves concave to conduplicate with keel sometimes developed (regardless leaves strongly conduplicate or not), 0.5-1.2 mm wide and 5-15 mm long, forming loose pure patches or as admixture to other hepatics and mosses; apical part of shoots sometimes become depauperate with scale-like leaves. Rhizoids sparse, mostly in the area of branch origin, brownish, erect spreading, separated or in loose fascicles. Stem brownish, from rhizomatous and freely branched base, above branching sparse, ventral, produces normally leaved branches or ventral leafless stolons; cross section somewhat to distinctly transversely elliptic, $110-250 \times 200-300 \mu \mathrm{m}$, with hyaloderm cells in one layer, with somewhat thickened walls, cells very large,
$40-60(-70) \mu \mathrm{m}$ in diameter, inward suddenly become smaller, inner layer 7-10 cells high, thick-walled, with vestigial to small trigones, $15-25 \mu \mathrm{m}$ in diameter. Leaves dichotomously arranged, canaliculate to conduplicate, with commonly present keel (both in conduplicate and concave leaves), when flattened in the slide always remain conduplicate, when trying unfold commonly lacerate, from scale like and very small to $700 \times 500 \mu \mathrm{m}$ (folded size, therefore unfolded should reach $700 \times 1000 \mu \mathrm{m})$, divided by narrow sinus descending to $1 / 5-1 / 3$ of leaf length into two obtuse to acute lobes. Underleaves absent. Cells are similar across the leaf, in the leaf middle with slightly thickened walls, $20-38 \times 17-$ $30 \mu \mathrm{m}$, trigones virtually absent, cuticle smooth. [Dioicous. Leaves become large to gynoecia. Gynoecia terminal on leading branches, without subfloral innovations; perianth deeply triplicate, 2-3-stratose in lower half and unistratose 
above, to $1.2 \mathrm{~mm}$ long and $0.6 \mathrm{~mm}$ wide; bracts folded, but not or hardly winged, margins entire or with a few teeth; bracteole present $1(-2)$ per gynoecium, unequally bilobed with smaller lobe commonly reduced to the tooth and then bracteole looks lanceolate. Androecia virtually intercalary, but branch never realize after androecia and die, bracts monandrous, antheridia spherical, 100-120 $\mu \mathrm{m}$ in diameter on short biseriate stalk. (Kitagawa 1982)] (Figures 2, 3).

The newly obtained data permit to discuss the distribution of the species, also basing on the result of our revision of available material. Holotype of the species is from Kyushu (Oita Pref.). Two more paratypes cited by Kitagawa (1982) are from Honshu: Hiroshima Pref. and Wakayama Pref. (all were studied in KYO and HIRO). Besides HIRO houses three more specimens of the species; all of them are from nearly the same place (see specimens examined in Material and Methods). VB collected Hygrobiella nishimurae in two localities.

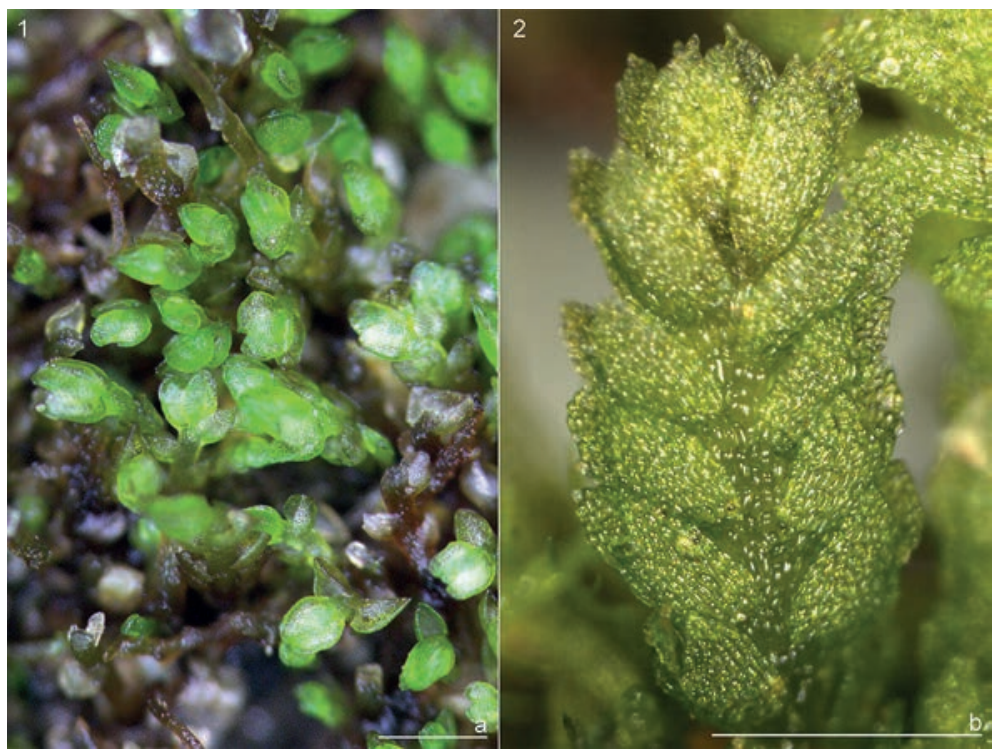

Figure 3 Hygrobiella nishimurae N. Kitag.: 1 - plant cushion; 2 - plant habit, dorsal view. Scales a $-1 \mathrm{~mm}$, for 1; b - 500 $\mu \mathrm{m}$, for 2. 1 - from Bakalin J-11-42-15, 2 from Bakalin Kor-30-58-15 (all in VBGI)

One of them is in Shikoku (Kochi Pref.) and is the new record of the taxon for that island. Another collection is from Jeju Island in the Republic of Korea. Therefore all known records of this species (both published before and revealed by us) are in the narrow band between 33 and $35^{\circ} \mathrm{N}$ stretching from Japanese Honshu, Shikoku and Kyushu to Jeju Island in Korea. Within that latitudinal limit the species is also limited altitudinally, all known collections are between 300 and $800 \mathrm{~m}$ a.s.l.

The species distribution is restricted to warm temperate moist forests with many evergreen broadleaved trees and the area type of the taxon may be called as Japan-Korea warm temperate. The species may decrease the population due to absence or rarity of sporophyte production. We were not able to find androecia or perianths in our recent collections. The holotype and the specimen from Wakayama Pref. although bears perianths and androecia, but have no traces of spore production. The latter may explain noticeable rarity of the taxon. The population observed in Jeju Island is very small, represented by dwarf sterile plants and may disappear within a few years. The probability of occurrence of the taxon in other areas of Japan and Korean Peninsula seems to be high. However we are not inclined to expect its distribution in adjacent areas like China and the southern flank of the Russian Far East. We estimate this taxon as strict KoreanJapanese endemic species that require conservation actions.

By ecological requirements this taxon is acidophilic that is similar to another taxa of Hygrobiella, although in the moisture requirements it looks more drought tolerant in comparison with other taxa of the genus and seems survive in the course of dry periods. Two recent collections are from moist rocks that however sometimes (probably rarely) become dry. The collections available in the herbaria have unclear references to moist to wet rocks without indication whether these rocks could be dry or not. We estimate ecologically this species may be called as acidophilic hygrophyte, but not hydrophyte as e.g. H. laxifolia.

\section{ACKNOWLEDGEMENTS}

Authors are sincerely grateful to Mr. M. Bakalin for line drawings for the present account, as well as to curators of HIRO and KYO for providing of necessary facilities for our study and Dr. M. Higuchi (TNS) for financial support and collaboration in the field researches in Shikoku in 2015. The work was partially supported Russian Foundation for Basic Researches (17-04-00018).

\section{LITERAT URE CITED}

Bakalin, V.A. \& A.A. Vilnet 2012. New combinations and new species of Solenostoma and Plectocolea (Solenostomataceae) from the Russian Far East. The Bryologist 115(4): 566-584.

Bakalin, V.A. \& A.A. Vilnet 2014. Two new species of the liverwort genus Hygrobiella Spruce (Marchantiophyta) described from the North Pacific based on integrative taxonomy. Plant Systematic and Evolution 300(10): 2277-2291.

Bakalin, V.A., A.A. Vilnet \& Y. Xiong 2015. Mesoptychia chinensis sp. nov. (Jungermanniaceae, Marchantiophyta) and comments on the distribution of Mesoptychia south of the boreal zone in Southern and Southeastern Asia. Journal of Bryology 37(3): 192-201.

Feldberg, K., J. Heinrichs, A.R. Schmidt, J. Váňa, H. Schneider 2013. Exploring the impact of fossil constraints on the divergence time estimates of derived liverworts. Plant Systematic and Evolution 299: 585-601.

Grolle, R. 1984. Miscellanea Hepaticologica 221-230. Journal of the Hattori Botanical Laboratory 55: 501-511

Guindon, S., J.F. Dufayard, V. Lefort, M. Anisimova, W. Hordijk \& O. Gascuel. 2010. New algorithms and methods to estimate maximum-likelihood phylogenies: assessing the performance of PhyML 3.0. Systematic Biology 59: 307-321.

Hall, T.A. 1999. BioEdit: a user-friendly biological sequence alignment editor and analysis program for Windows 95/98/NT. Nucleic Acids Symposium Series 41: 95-98.

Keane, T.M., T.J. Naughton \& J.O. McInerney 2004. ModelGenerator: amino acid and nucleotide substitution model selection. Available from: http://bioinf.may.ie/software/modelgenerator/ (last access July 2018). 
Kitagawa, N. 1982. A remarkable new species of Hygrobiella from Japan. Miscellanea Bryologica Lichenologica 9: 69-72.

Mamontov, Yu.S., N.A. Konstantinova, A.A. Vilnet, A.D. Potemkin, E.V. Sofronova \& N.S. Gamova 2018. On resurrection of Marsupella parvitexta Steph. (Gymnomitriaceae, Marchantiophyta) as a semi cryptic species of the genus Gymnomitrion. Nova Hedwigia 106(1-2): 81-101.

Pattengale, N.D., M. Alipour, O.R.P. Bininda-Emonds, B.M.E. Moret \& A. Stamatakis 2010. How many bootstrap replicates are necessary? Journal of Computational Biology 17:337-354.

Shaw, B., B. Crandall-Stotler, J. Váňa, R.E. Stotler, M. von Konrat, J.J. Engel, E.Ch. Davis, D.G. Long, P. Sova \& A.J. Shaw. 2015. Phylogenetic relationships and morphological evolution in a major clade of leafy liverworts (phylum Marchantiophyta, order Jungermanniales): suborder Jungermanniineae. Systematic Botany 40(1):27-45.

Shaw, J., E.B. Lickey, J. Beck, S.B. Farmer, W. Liu, J. Miller, K.C. Siripun, C. Winder, E.E. Schilling \& R.L. Small 2005. The tortoise and the hare II: relative utility of 21 noncoding chloroplast DNA sequences for phylogenetic analysis. American Journal of Botany 92:142-166.

Söderström, L., A. Hagborg, M. von Konrat, S. Bartholomew-Began, D. Bell, L. Briscoe, E. Brown, D.C. Cargill, D.P. Costa, B.J. Crandall-Stotler, E.D. Cooper, G. Dauphin, J.J. Engel, K. Feldberg, D. Glenny, S.R. Gradstein, X. He, J. Heinrichs, J. Hentschel, A.L. Ilkiu-Borges, T. Katagiri, N.A. Konstantinova, J. Larran, D.G. Long, M. Nebel, T. Pôcs, F. Felisa Puche, E. Reiner-Drehwald, M.A.M. Renner, A. Sass-Gyarmati, A. Schâfer-Verwimp, J.G.S. Moragues, R.E. Stotler, P. Sukkharak, B.M. Thiers, J. Uribe, J. Váňa, J.C. Villarreal, M. Wigginton, L. Zhang \& R.-L. Zhu 2016. World checklist of hornworts and liverworts. PhytoKeys 59:1-828.

Stamatakis, A. 2006. RAxML-VI-HPC: Maximum likelihood-based phylogenetic analyses with thousands of taxa and mixed models. Bioinformatics 22:2688-2690.
Taberlet, P., L. Gielly, G. Pautou \& J. Bouvet 1991. Universal primers for amplification of three non-coding regions of chloroplast DNA. Plant Molecular Biology 17:1105-1109.

Tamura, K., D. Peterson, N. Peterson, G. Stecher, M. Nei \& S. Kumar 2011. MEGA 5: Molecular Evolutionary Genetics Analysis using maximum likelihood, evolutionary distance, and maximum parsimony method. Molecular Biology and Evolution 28:2731-2739.

Váňa, J., L. Söderström, A. Hagborg \& M. von Konrat 2013. Notes on early land plants today. 41. New combinations and synonyms in Cephaloziaceae (Marchantiophyta). Phytotaxa 112(1):7-15.

Vilnet, A.A, N.A. Konstantinova \& A.V. Troitsky 2012. Molecular phylogeny and systematics of the suborder Cephaloziineae with special attention to the family Cephaloziaceae s.l. (Jungermanniales, Marchantiophyta). Arctoa 21:113-132.

Vilnet, A.A., N.A. Konstantinova \& A.V. Troitsky 2010. Molecular insight on phylogeny and systematics of the Lophoziaceae, Scapaniaceae, Gymnomitriaceae and Jungermanniaceae. Arctoa 19:31-50.

White, T.J., T. Bruns, S. Lee \& J. Taylor 1990. Amplification and direct sequencing of fungal ribosomal RNA genes for phylogenetics. In: PCR protocols: a guide to methods and applications (M.A. Innis, D.H. Gelfand, J.J. Snisky \& T.J. White, eds.), pp. 315-322. San Diego.

Yamada, K. \& Z. Iwatsuki 2006. Catalog of the hepatics of Japan. Journal of the Hattori Botanical Laboratory 99:1-106.

Yatsentyuk, S.P., N.A. Konstantinova, M.S. Ignatov, J. Hyvönen \& A.V. Troitsky 2004. On phylogeny of Lophoziaceae and related families (Hepaticae, Jungermanniales) based on $\operatorname{trn} \mathrm{L}-\mathrm{F}$ intron-spacer sequences of chloroplast DNA. In: Molecular systematics of bryophytes (B. Goffinet, V. Hollowell \& R.E. Magill eds). Monographs in Systematic Botany from the Missouri Botanical Garden 98:150-167. 